Tomasz Hermaniuk, Joanna Rosak-Szyrocka

\title{
QUALITY OF POLISH POST SERVICES IN THE OPINION OF CUSTOMERS
}

\begin{abstract}
Summary: The postal services market in Poland in recent years opened up to competition. Gradually was reduced an area of services reserved for the public operator and at the same time increased market competition. Opening of the market forced the the Polish Post to face the market competition in all areas of its business. In view of these changes of particular importance becomes the need to adopt an approach aimed to meet the needs of consumers, in which the quality of the offer will be a priority item.

The purpose of this article is to present the results of studies on the quality of the offer of Polish Post in the opinion of its customers.
\end{abstract}

Key words: quality, service quality, Polish Post

\section{Introduction}

Postal services are of strategic importance for the economy of each country and are largely related to other important sectors, such as ecommerce, insurance, banking, which strictly depend on the postal infrastructure (ZARĘBA 2008).

An important issue for several years was the preparation of the Polish Post for the functioning on the liberalized market. That was because it is the largest player in the postal services and shape of the market at a large extent depends both on the decision of the state to the operator, as well as actions taken by that enterprise. Quality is an element that should be the determining factor when choosing a service. Polish Post in recent years began to develop dynamically expanding its scope of business activities and introducing new services. Entering the market enterprises providing postal services made the Polish Post began to fight for the client by introducing additional services and improving the quality of existing services. Hence, the purpose of this article is an attempt to verify the level of quality of services provided by the Polish Post in the opinion of its customers. 


\section{The issue of service quality}

The service sector includes both consumer services and services purchased by institutions and in particular businesses. The specificity of marketing of services is not related to dissimilarity needs and behaviors of buyers, but to the nature of services themselves as a basic component of a service composition of marketing instruments. Specificity of services determines the nature of the service marketing strategies applicable in this sector. A special emphasis is put on developing a positive image of the company and gaining confidence of a potential customer, in order to distinguish its own offer (ALTKORN 2004).

The perception of service quality consists of a combination of determinants related to three intersecting base areas of service delivery: people, process service, material evidence of services. Due to the fact that the offer of the service provider is generally to a greater extent intangible, purchasers search for material evidence, namely the service elements that are possible to estimate prior to the acquisition of services. All components of service, namely people, process and its organization, also material evidence associated with it, are present at any meeting of recipients and providers. They provide purchaser the opportunity to comparisons of many service offerings, thus play a significant role in the creation of customer satisfaction (STYŚ 2003).

J. Lehtinen considered three aspects of service quality at three levels (URBAN 2007):

- material quality (basic level) - including the material elements, the ingredients, the tools and the environment of the service,

- quality of interaction (level of interaction) - the relationship between the customer and the organization,

- quality of the company (the level of the entire organisation) tradition, culture, organisation, perception of its clients.

The total service quality perceived by the customer will always be the result of a confrontation quality expected (requirements and customer needs) and quality experienced (quality of service). Evaluation of the quality of services is hampered by their immateriality. The service is 
carried out during the interaction with the client, so it is impossible to design the perfect service or to assess its quality in advance. Each service process is unique, and the essence of the contribution of the human factor causes variability of effect and evaluation of services. This assessment depends primarily on the earlier expectations of the client, and his satisfaction with services is a function of fulfilled expectations. Customer expectations are not fixed and depend on many factors. These include: price, customer needs, previous experience, the company's image, the promises made by the service provider, the information obtained from the environment.

From the above considerations two conclusions can be drawn. First, the quality of service is a subjective issue. The perception of quality may result from causes that have a weak relationship with the same service or process its benefits. Second, the quality of service and its evaluation by the customer is not constant in time, quality analysis therefore requires continuous study of changes in the level of customer satisfaction.

\section{Characteristics of postal services market in Poland}

The activities of the public postal operator is of particular importance in the economy. In most countries, its functioning is perceived in terms of the services of public utility, and important place in the hierarchy of objectives is the provision of the universal services (PANASIUK 2003).

Public postal companies operate in area of provision of several groups of services such as:

- sending letters and postcards,

- sending packagess,

- courier shipments,

- financial services, banking, postal orders,

- logistics service companies

- e-commerce services.

Year 2013 was a breakthrough for the postal services market in Poland. So far it has evolved gradually in the direction of opening to competition. Systematically decreased area of services reserved for 
universal service provider and at the same time market competition increased. Since the 1 of January 2013 there was a complete opening of the market. At the end of 2013, in addition to the Polish Post were 274 registered operators.

Polish Post is a company with 455 years of tradition, the largest operator on the domestic market, with more than 7,500 branches and postal agencies that provide services to individual and business customers (http://www.poczta-polska.pl).

In 2013, the operator has realized in the domestic and foreign market nearly 2 billion postal services, which resulted in nearly 5 billion PLN of revenue. In this number of services more than 0.8 billion constituted universal services, the revenues of which amounted to nearly 3.3 billion PLN. A significant part of that (98\%) of the universal service charges constituted letters. Their participation in group of universal services revenue amounted to more than $81 \%$. Alternative postal operators in 2013 delivered over 2.9 billion postal services which resulted in more than 2.5 billion PLN of revenue.

In terms of size of revenue the largest part constitutes courier shipments. Revenues from this segment amounted to nearly $86 \%$ of all revenues generated by the remaining postal operators. In 2013 Polish Post had over $69 \%$ share in the volume of letters and close to $80 \%$ of total revenues from these shipments. A similar situation was in the area of shipment of packages. More than $82 \%$ of volume and $86 \%$ of the revenue in this segment of the market has been realised by the Polish Post. Speak of a different situation in terms of courier shipments where the vast advantage in the reporting period had alternative operators. Over $97 \%$ in volume and $95 \%$ of the revenue from this activity belongs them (Report on the state of the postal market for 2013).

\section{Quality of the Polish Post services in the opinion of customers}

The study was conducted in May 2013 on a sample of 189 respondents. As a research tool was used the questionnaire. Respondents 
were asked questions dealing with various aspects related to the quality of services offered by the company.

The first question concerned the type of services used by the respondents and the frequency with which they do it. The results are shown in table 1.

Table 1. Average frequency of use of the Polish Post services (in \%).

\begin{tabular}{|l|r|r|r|r|r|}
\hline \multirow{2}{*}{ Type of service } & \multicolumn{5}{|c|}{ Average frequency of use } \\
\cline { 2 - 6 } & $\begin{array}{c}\text { Several } \\
\text { times a } \\
\text { year }\end{array}$ & $\begin{array}{c}\text { Once a } \\
\text { month }\end{array}$ & $\begin{array}{c}\text { Several } \\
\text { times a } \\
\text { month }\end{array}$ & $\begin{array}{c}\text { Several } \\
\text { times a } \\
\text { week }\end{array}$ & Not at all \\
\hline Payments of bills & 19.0 & 16.4 & 4.2 & 2.1 & 58.2 \\
\hline Shipment of letters & 54.5 & 12.2 & 11.6 & 2.6 & 19.0 \\
\hline Shipment of packages & 42.9 & 8.5 & 6.9 & 2.1 & 39.7 \\
\hline Financial services & 15.9 & 5.8 & 6.9 & 2.1 & 69.3 \\
\hline
\end{tabular}

Source: own study based on performed research.

As is apparent from the data presented in Table 1, the vast majority of customers using the services of the Post, does it at least a few times a year. The most frequently used service in the offer $(81 \%)$ is shipment of letters and this service is used most often $-54.5 \%$ of the respondents use it several times a year. The second most used service is shipment of packages. This service is used by $60.3 \%$ of surveyed customers. Most respondents does this several times a year (42.9\%). When it comes to bill payments, the respondents most frequently used this service once a month $(16.4 \%)$ or several times a year $(19.0 \%)$, however the majority declared that they do not use this service at all (58.2\%). Only a small percentage of respondents $(30.70 \%)$ declare the use of the financial services of the Polish Post.

Another issue in the survey were the reasons for using the services of the Polish Post. Respondents could select up to three responses. 


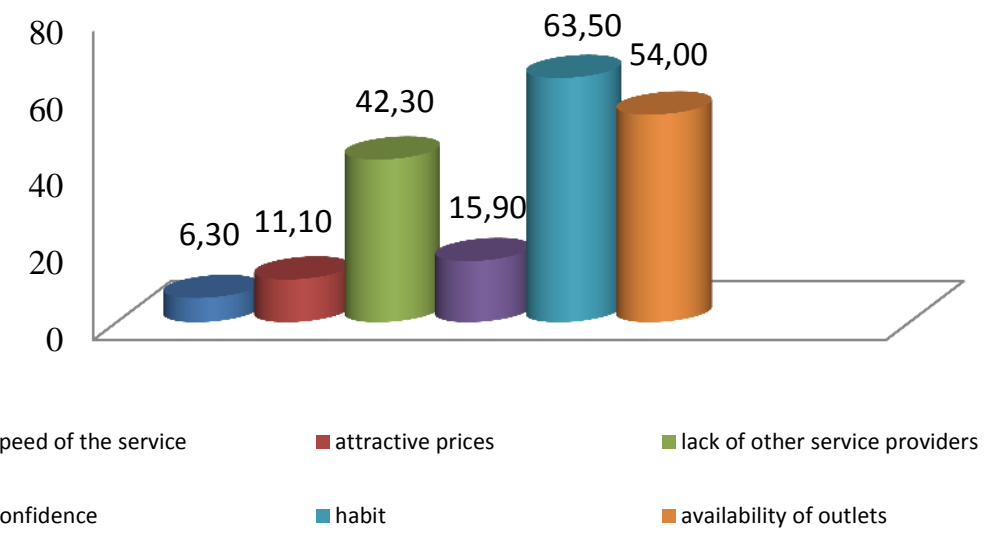

Fig. 1. Reasons of use of Polish Post services (\% of answers) Source: own study based on performed research.

Approximately two thirds of respondents (63.50\%) use the services of the Polish Post out of habit. The next 54\% does it due to the general quantity of available outlets and the lack of other service providers (42.30\%). The smallest percentage of indications accounted for quick execution of services $-6.30 \%$. Analysing the results it can be concluded that customers are guided by their habits despite the convenience that reflects on the quality.

In the next part of the survey respondents were asked to point out which elements of customer service are important to them. In the first place it is culture and friendliness of the service (70.40\%), the second indicates the service speed (59.30\%), then the waiting time for services (56.60\%). The least important element of the quality of customer service is the way of presentation of the offer by the employee (19.00\%)

The level of quality of services, consists of a variety of its elements. For each of the recipients the evaluation of their will be different, as well as the importance of this element in the service, will be perceived differently by different groups of customers. Therefore, the next question concerned the evaluation of service elements, which are the most important for the customers. The results are shown in table 2 . 
Table 2. Assessment of the elements of Polish Post services (in \%) 1 - "very low level", 5 - "very high level".

\begin{tabular}{|l|r|r|r|r|r|}
\hline \multirow{2}{*}{\multicolumn{1}{c|}{ Specification }} & \multicolumn{6}{c|}{ Assessment } \\
\cline { 2 - 6 } & \multicolumn{1}{c|}{$\mathbf{1}$} & \multicolumn{1}{c|}{$\mathbf{2}$} & \multicolumn{1}{c|}{$\mathbf{3}$} & \multicolumn{1}{c|}{$\mathbf{4}$} & \multicolumn{1}{c|}{$\mathbf{5}$} \\
\hline Prices of letter post & 3.7 & 16.9 & 42.3 & 29.6 & 7.4 \\
\hline Prices of package shipment & 7.4 & 19.0 & 46.6 & 22.8 & 4.2 \\
\hline Competence and knowledge of staff & 6.9 & 15.9 & 30.2 & 35.4 & 11.6 \\
\hline Quality of customer service & 7.4 & 21.2 & 27.5 & 34.9 & 9.0 \\
\hline Appearance and equipment of outlets & 6.3 & 18.0 & 27.5 & 39.2 & 9.0 \\
\hline Location of outlets & 2.1 & 4.8 & 21.7 & 48.1 & 23.3 \\
\hline Quality of financial services & 8.5 & 12.7 & 46.6 & 29.1 & 3.2 \\
\hline
\end{tabular}

Source: own study based on performed research.

Among the various elements of the quality of postal services, the respondents rated the quality of service $(28.6 \%$ of respondents gave low and very low score). Prices of postal items were rated as average by $46.6 \%$ of respondents. Similarly was rated the quality of financial services. For items that were rated as "good" and "very good" by the study group include, location of facilities design and equipment of outlets. Can be inferred that the strength of the Polish Post, in particular, are the location and appearance of outlets and their equipment.

In the next question, respondents evaluated the individual components influencing the quality of the customer service of the Polish Post. The results are shown in Table 3.

According to the presented data, the lowest were assessed three aspects of the service. The waiting time for service, service speed, and the presentation of the offer by the employee. Items that were rated as "good" and "very good" by the study group include competence of personnel, culture and friendliness of service. Can be inferred that the opinion of the respondents are very divided when it comes to assessing the quality of customer service. 
Table 3. Assessment of the quality of the Polish Post customer service (in \%) 1 - "very low level", 5 - "very high level".

\begin{tabular}{|l|r|r|r|r|r|}
\hline \multirow{2}{*}{\multicolumn{1}{|c|}{ Specification }} & \multicolumn{6}{c|}{ Assessment } \\
\cline { 2 - 6 } & \multicolumn{1}{|c|}{$\mathbf{1}$} & \multicolumn{1}{c|}{$\mathbf{2}$} & \multicolumn{1}{l|}{$\mathbf{4}$} & \multicolumn{1}{c|}{$\mathbf{5}$} \\
\hline Competence of staff & 2.6 & 10.1 & 35.4 & 40.7 & 11.1 \\
\hline Way of presenting the offer & 3.7 & 18.5 & 33.3 & 37.6 & 6.9 \\
\hline Culture and friendliness of service & 5.8 & 13.8 & 33.9 & 33.9 & 12.7 \\
\hline Operating time & 8.5 & 25.9 & 34.4 & 26.5 & 4.8 \\
\hline Waiting time for service & 20.1 & 28.6 & 32.3 & 17.5 & 1.6 \\
\hline
\end{tabular}

Source: own study based on performed research

In the next part of the survey respondents had the opportunity to speak out about the use of the financial services of the Polish Post. The results are shown in Table 4.

Table. 4. Use of financial services of the Polish Post (in\%).

\begin{tabular}{|l|r|}
\hline \multicolumn{1}{|c|}{ Answer } & \% of answers \\
\hline I did not know that the post office provides such services & 16.4 \\
\hline I prefer the traditional financial service providers & 50.3 \\
\hline post office is not a place for the provision of such services & 29.6 \\
\hline services provided are not adapted to the needs of consumers & 9.5 \\
\hline $\begin{array}{l}\text { I do not have confidence in the quality of this type of service } \\
\text { provided by the post office }\end{array}$ & 30.2 \\
\hline Post Office does not have adequate infrastructure & 19.0 \\
\hline
\end{tabular}

Source: own study based on performed research.

Based on the data can be indicated that the main reasons for not using financial services by the respondents is the fact that they prefer the traditional providers of financial services $(50.3 \%)$. In second place 
(30.2\% of responses) was the opinion that the respondents do not have confidence in the quality of this type of services provided by the post office. The third most commonly suggested opinion $(29.6 \%$ of respondents) is the note that post office is not a place for the provision of such services.

In many cases the information coming from the customers is an invaluable tool that can be used in the pursuit of continuous improvement. Therefore, in the next part of the survey respondents were asked to point which of the following statements concerning the Polish Post is true. The question was multiple-choice and maximum number of answers is 3 results are shown in Table 4

Table 4. General opinions of customers about Polish Post (w \%).

\begin{tabular}{|l|r|}
\hline \multicolumn{1}{|c|}{ Specification } & \% of answers \\
\hline Fast and professional service & 12.2 \\
\hline Long time of waiting for the service provided & 55.0 \\
\hline Customer expectations are met & 10.1 \\
\hline Services are not adapted to the needs of consumers & 18.5 \\
\hline Service prices are too high & 37.0 \\
\hline Quality of service is adequate to the price & 27.0 \\
\hline
\end{tabular}

Source: own study based on performed research.

Analyzing the data presented in table 4, it can be concluded that most of the respondents (55\%) considered that the statement saying about long time of waiting for the service. The high price of services sees $37 \%$ of respondents. Of the respondents $27 \%$ stated that the quality of service is adequate to the price, and $18.5 \%$ claim that services are not adapted to the needs of consumers.

Another question concerned the opinion of respondents on the Polish Post. The question was multiple choice answers with the maximum number of 3 . Results are shown in figure 2. 


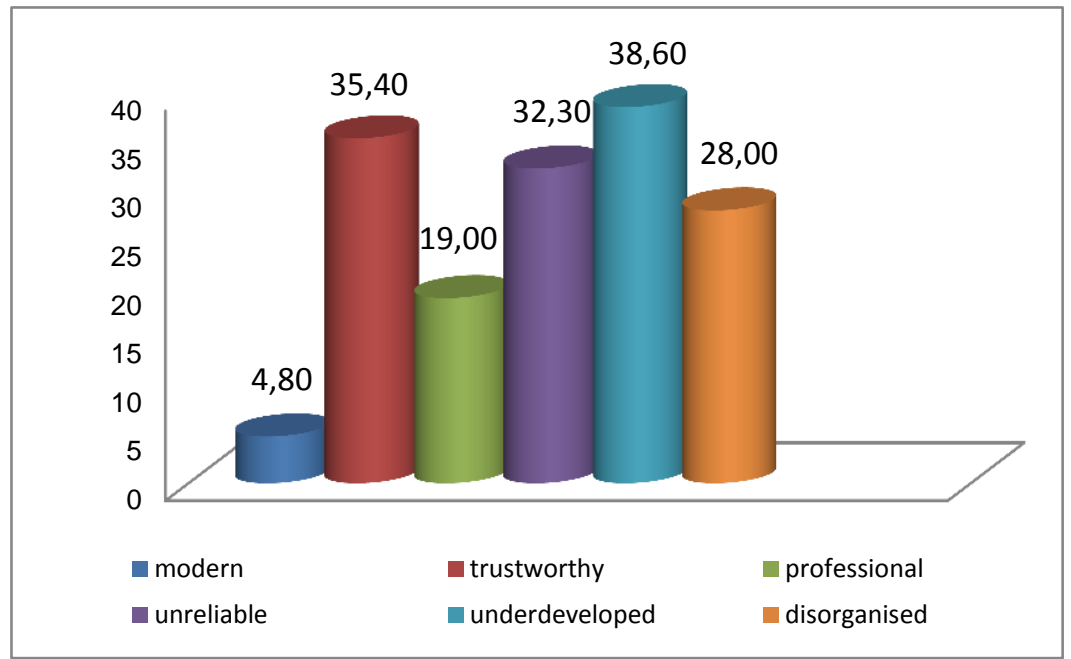

Fig. 2. Statements describing the Polish Post (in \%) Source: own study based on performed research.

Analyzing the data presented in Figure 2 it can be concluded that the vast majority of respondents believe that the Polish Post is an underdeveloped $(38.60 \%)$, unreliable $(32.30 \%)$, disorganised $(28.00 \%)$. Nevertheless, the Polish Post has a reputation of a trustworthy (35.40\%).

\section{Summary}

Quality of service is presently the subject of increased interest in theoretical considerations, but also in the practice of modern enterprises. Understanding the reasons for the choice of the service provider and assessment of the quality of services, makes it possible to better align the 
company's offer to the expectations of current and potential customers, and gives a better chance to gain a competitive advantage.

Results of the research show the opinions and the condition of satisfaction of customers of the Polish Post. Analyzing these conclusions can be drawn that in the functioning of the company can be indicated at least a few areas that need to be improved. Results prove that, despite structural and organizational changes constantly taking place in the enterprise, problems that existed previously still unsolved.

\section{Bibliography}

1. AltKorn J. 2004. Podstawy marketingu. PWN. Kraków.

2. ВІеSкOK G. 2013. Logistyka ustug. Cedewu. Warszawa.

3. Czubata A. 2006. Marketing ushug. Oficyna ekonomiczna. Warszawa.

4. Czubąa A., Jonas A., SMoleń T., Wiktor J. W. Marketing ustug

5. Flejterski F., Panasiuk A., Perenc J., Rosa G. 2005. Wspótczesna ekonomika ustug. PWN. Warszawa.

6. FURTAK R. 2003. Marketing partnerski na rynku ustug. PWE. Warszawa.

7. KOCHANIEWSKA M. 2003. Kultura jakości. Jak odnieść sukces w turystyce. Eurosystem. Warszawa.

8. PANASIUK A. 2003. Ustugi pocztowe. Rynek i marketing. PWN. Warszawa.

9. SARGEANT A. 2004. Marketing $w$ organizacjach non profit. Oficyna Ekonomiczna. Kraków.

10. STYŚ A. (red.). 2003. Marketing uslug. PWN. Warszawa.

11. SURESHCHANDAR G. S. i in. 2012. The relationship between management's perception of total quality service and customer perceptions of service quality. Total Quality Menagement, Volume 13.

12. URBAN W. 2007. Definicje jakości usług - różnice oraz ich przyczyny. Problemy Jakości Nr 3/2007.

13. ZARĘBA A. 2008. Rynek ushug pocztowych. Wydawnictwo Uniwersytetu Warmińsko-Mazurskiego. Olsztyn.

14. Urząd Komunikacji Elektronicznej, Raport o stanie rynku pocztowego za 2013 rok, Warszawa, 2013. 